\title{
AN ANALYSIS ON TRADERS' INCOME AND ECONOMIC MOTIVATION TOWARD THEIR BEHAVIOR IN PAYING ZAKAT COMMERCIAL
}

\author{
Nely Novia ${ }^{1}$, Iswan Noor ${ }^{2}$, Marlina Ekawaty ${ }^{3}$ \\ Economics and Business Faculty, University of Brawijaya \\ Email: ${ }^{1}$ nelynovia8@gmail.com, ${ }^{2}$ iswannoor@yahoo.co.id, \\ 3marlina_ekawaty@yahoo.com
}

\begin{abstract}
This study intends to determine and analyze the influence of economics factor: income $\left(X_{1}\right)$ as well as economic motivation $\left(X_{2}\right)$ towardMadurese traders' behavior in paying zakat commercial (Y). To analyze the data, multinomial logit (Mlogit) model was employed. The result of this study indicated, as simultaneously, income $\left(X_{1}\right)$ and economic motivation $\left(X_{2}\right)$ greatly influences Madurese traders' behavior in paying zakat commercial (Y). And partially, Madurese traders' behaviorin payingzakat commercial (Y) was affected by income $\left(X_{1}\right)$ and economic motivation $\left(X_{2}\right)$ as well.

Keywords: income, economic motivation, zakat commercial.
\end{abstract}

\section{INTRODUCTION}

Poverty is still becoming the most perennial economic problem. Various policies such as tax, Bantuan Langsung Tunai (BLT), fuel subsidies, and beras miskin (raskin) has been made by the government to solve that problem. The result is predictable. In other words, this is not effective enough to diminish the poverty in Indonesia. On the other side, Islamic economic considers poverty might be solved by expending that donation to the productive venture capital and for consumption purpose. Basically, zakat commercial is intended to distribute ones income equitably and also for bringing about the social justice and economic welfare. The one who is obligated to pay zakat, muzakki, needs to reach haul (one year) and nisab (counted as gold 85 gram) in accordance to the rule.

Potential of zakat in Indonesia goes along with the huge number of Moslem which means this is very good. Unfortunately, there is no any legislation yet about zakat in this country. 
It has indirect influence to people awareness in paying zakat. As the effect, Badan Amil Zakat face a great difficulty in collecting the zakat. The data collected by Direktorat Pemberdayaan Zakat and BAZNAS on 2012 showed that almost 2.2 trillion are gathered nationally (cited from Kementerian Agama RI Direktorat Jenderal Bimbingan Masyarakat Islam Direktorat Pemberdayaan Zakat, 2013). From this occurrence, the whole related parties need to cooperate cohesively to increase the gathered zakat.

Malang, one of the biggest cities in East Java, becomes an urban area for most people to work, study or even speculate. The most of people come to Malang are Madurese. Each of them have similar intention that is getting better job with more income indeed. The problem is they do not have enough preparation such as a proper educational background. Consequently, trading becomes their only choice since most of Madurese graduate from primary school. They believe Malang can guarantee their life by providing complete facilities and offering rapid economic development.

The most highlighted aspect in Malang is trading sector that also turns into a mainstay because of many people work as traders. Table 1 below will tell about information of 15 years up and what they work for.

Table 1. Population of 15 years which work for the main business field in Malang during 2013-2014

\begin{tabular}{|c|c|c|c|}
\hline \multirow[t]{2}{*}{ No. } & \multirow[t]{2}{*}{ Business Field } & \multicolumn{2}{|c|}{$\begin{array}{l}\text { Population of } 15 \\
\text { years which work } \\
\text { for the main } \\
\text { business field }\end{array}$} \\
\hline & & 2013 & 2014 \\
\hline 1. & Agriculture & 4.996 & 7.778 \\
\hline 2. & Processing Industry & 85.284 & 87.912 \\
\hline 3. & Construction & 26.475 & 39.699 \\
\hline 4. & $\begin{array}{l}\text { Wholesaler, retailer, } \\
\text { Hotel and Restaurant }\end{array}$ & 137.501 & 116.432 \\
\hline 5. & $\begin{array}{l}\text { Transport, } \\
\text { Communication and } \\
\text { Warehouse }\end{array}$ & 25.478 & 19.679 \\
\hline 6. & Finance and Services & 114.531 & 119.046 \\
\hline 7. & $\begin{array}{l}\text { Excavation and } \\
\text { Mining, Electricity, } \\
\text { Water and Gas }\end{array}$ & 3.829 & 2.504 \\
\hline
\end{tabular}

Source: processed by the writers from Malang (2014) and (2015)

Table 1 shows that the main income of 15 years up is coming from trading. From this phenomenon, trade sector can be labelled as the key part in Malang. Also, it indicates that the most potential tax and zakat 
commercial are collected from trading. On the contrary, the previous study revealed the exact number of zakat commercial stuck on $2.02 \%$ even though it can reach 9 million up to 4.5 trillion IDR (Merlinda, 2015). Such an irony to compare the potential amount with the exact number that surely affected by several factors.

Another previous study proved the people avoidance in paying zakat is caused by economic factors: income and economic motivation. Bakar \& Rashid (2010) found that academics from the three faculties in International Islamic University of Malaysia (IIUM),whom paid zakat, were influenced by the assumption of paying zakat will certainly elevate the people economic condition. Other than that, a study by Siswantoro \& Nurhayati (2012) discovered motivation positively influence zakatespecially as an income tax deduction.

The other positive findings were completed by Merlinda (2015). She claimed that income capability had positive impact on how Moslem paid zakat. Next, Sobana (2016) got a result said that Moslem obedience in paying zakat maal influenced by their income capability. Similar finding also acquired by Perbawa and Abdullah (2016). They found income influenced positively on the awareness in paying zakat at $B A Z N A S$. Thesegood trends are also owned by Sedjati et al. (2018) that has similar finding with the others.

Simply said, this current study intends to figure out and analyze the economic factor: income $\left(\mathrm{X}_{1}\right)$ and economic motivation $\left(\mathrm{X}_{2}\right)$ toward Madurese traders' behavior in paying zakat commercial (Y). Then, hypothesis in this studysays that there is influence on income $\left(\mathrm{X}_{1}\right)$ and economic motivation towardMadurese traders' behavior in paying zakat commercial (Y).

\section{RESEARCH METHOD}

This study employed quantitative research method and utilized descriptive as the approach (Sugiyono, 2014). Independent 
variables of this study were income $\left(\mathrm{X}_{1}\right)$ and economic motivation $\left(\mathrm{X}_{2}\right)$ whilebehavior in paying zakat commercial (Y) acted as dependent variable. Thisstudy was done in Malang especially at three different market: Pasar Gadang, Pasar Besar, and Pasar Blimbing.

Furthermore, the writers chose nonprobability sampling with accidental sampling technique. Total number of the samples were 100 respondents. The primary data used in this study was collected by using open-questionnaire. Additionally, income variable used ratio scale and economicmotivationengaged likert scale. The economic motivation variable, used likert scale, applied four pointsof response such as sangat setuju $(S S)=4$, setuju $(S)=3$, tidak setuju $(T S)=2$ and sangat tidak setuju $(S T S)=1$. This scale was highly important to avoid the respondents in choosing neutral answerso the social bias could be avoided (Widhiarso, 2010). The economic motivation variable surely had been tested in advance by using validity and reliability test before it was employed as the instrument.

The writers analyzed their study by using multinomial logit (Mlogit) data analysis (Widarjono, 2010; Ghozali, 2011). Because the variables used in Mlogit analysis were basically combination of metric as well nonmetric variable so the economic motivation variable which was ordinal, it needed to convert to MSI. This econometric model below consists of income factor (X1) and economic motivation (X2) that influenceMadurese traders' behavior in paying zakat commercial (Y).

$$
\mathbf{Y}_{\mathrm{i}}=\boldsymbol{\alpha}+\boldsymbol{\beta}_{1} \mathbf{X}_{1 \mathrm{i}}+\boldsymbol{\beta}_{2} \mathbf{X}_{2 \mathrm{i}}+\mathbf{e}_{\mathrm{i}}
$$

$\mathbf{Y}_{\mathbf{i}}=$ dependent variable:Madurese traders' behavior in paying zakat commercial that is divided into three categories:

1. Not pay zakat commercial $(\mathrm{Y}=1)$

2. Occasionally pay zakat commercial $(\mathrm{Y}=2)$

3. Always pay zakat commercial $(\mathrm{Y}=$ 3)

$\boldsymbol{\alpha}=$ constant

$\mathbf{X}_{\mathbf{1}}=$ income 
$\mathbf{X}_{\mathbf{2}}=$ economic motivation

\section{RESULT AND DISCUSSION}

Most of Madurese traders have these income capability as follows.

Table 2. Range of Madurese Traders Income

\begin{tabular}{lcc}
\hline Category & \multicolumn{1}{c}{ Range of net income } & $\%$ \\
\hline Low & $\begin{array}{l}<50 \text { million }- \text { Rp.150 million } \\
\text { IDR }\end{array}$ & $56 \%$ \\
& & \\
\hline Moderate & $>150$ million - 250 million IDR & $37 \%$ \\
\hline High & $>250-350$ million IDR & $7 \%$ \\
\hline & & $100 \%$ \\
& Total Percentage &
\end{tabular}

Source: The result of study processed by the writers(2017)

According to table 2, most of Madurese traders have low (56\%) and average income (37\%). Whereas, only a few number of Madurese traders have high income capability $(7 \%)$.

Next is Madurese traders' economic motivation $\left(\mathrm{X}_{2}\right)$. The table below deliberates statements of economic motivation used in the current study.

\section{Tabel 3. Statements of Economic Motivation}

\begin{tabular}{ll}
\hline No. & Statements of Economic Motivation \\
\hline 1. & $\begin{array}{l}\text { By paying zakat commercial, it is one of the } \\
\text { ways to make wealth distributed equally. }\end{array}$ \\
\hline
\end{tabular}

2. Iam sure Allah will multiply my wealth when I pay zakat commercial.

3. I believe I can develop my own business by paying zakat commercial.

4. I pay zakat commercial to purify my wealth and make it to be blessed by Allah.

5. I pay zakat commercial to diminish poomess.

6. I pay zakat commercial to help people in needs
to pay the debt off. By paying zakat commercial, it increases

7. productive venture capital to help the people in needs.

Source: The result of study processed by the writers(2017)

Based on table above, most of Madurese traders (97\%) consider paying zakat commercial as one of the ways to distribute wealth equally, purify the wealth to make it blessed by Allah, and diminish poorness. Then, they consider paying zakat commercial can help people in needs to pay the debt off (55\%) andproductive venture capital to help the people in needs (72\%).

Moreover, Madurese traders believe Allah will multiply their wealth if they pay zakat commercial and their business will be developed (97\%). The least number of Madurese traders says they do not agree paying 
zakat commercial to help people in needs pay off their debts.

Tabel 4. Range of Madurese traders' Economic Motivation

\begin{tabular}{lcc}
\hline Category & Range of Economic Motivation & \% \\
\hline Low & $7-<14$ & $0 \%$ \\
\hline Average & $14-<21$ & $13 \%$ \\
\hline High & $21-<28$ & $87 \%$ \\
\hline & Total Percentage & $100 \%$ \\
\hline
\end{tabular}

Source: The result of study processed by the writers (2017)

Table 4 shows that majority of the Madurese traders have high economic motivation (87\%) and also low (13\%).

These are the results of validity and reliability test. The first one was validity test that tells coefficient valuer himmg $_{\text {between }} 0.504-$ $0.788>r_{\text {tabel }}(0.197)$ or sig. coefficient value. All indicators of economic motivation $0.000<$ 0.05 meant the whole indicators on economic variable were valid. The second was reliability testwhich conveyed coefficient value of Cronbach's Alpha was $0.767>$ reliability coefficient value 0.60 . In other words, the indicator at economic motivation was reliable.

After that, Mlogit test was done. Firstly, assumption test conducted to see whether there was correlation between income variable $\left(\mathrm{X}_{1}\right)$ and economic motivation $\left(\mathrm{X}_{2}\right)$ or not. The outcome was $0.421<0.8$ and it meant there was no any multicollinearity.
Secondly,Goodness of Fit test $\left(\mathrm{R}^{2}\right)$ by using Pseudo R-Square Nagelkerke $\mathrm{R}^{2}$ showed 0.450 . It said $45 \%$ of income variable (X1) and economic motivation (X2) was able to explain the various Madurese traders' behavior in paying zakat commercial's responsibility. For the rest, 55\%, was clarified by the other variable did not exist in the model.

For the third, the accuracy of prediction by looking at coefficient of Classification Overall Percentage was 68\%. It meant Madurese traders' behavior in paying zakat commercial could be predicted up to $68 \%$ accuracy by the model. The fourth is appropriateness of model by looking at Goodness of Fit Sig, Pearson Chi-Square 0.491 and Sig. Deviance Chi-Square 0.987>a $(0.05)$ that meant this model could explain it well.

The next phase was simultaneous test by watching Model of Fitting Information Likelihood Ratio Test Sig. Chis-Square 49.521 with 4 or 9.48773 degrees of freedom and Sig. 5\% level. The value of Chi-Square test $>$ Chi-Square table $(49.521>9.48773)$ and Sig. value $<\alpha$ value $(0.000<0.05)$ which was income variable $\left(\mathrm{X}_{1}\right)$ and economic motivation $\left(\mathrm{X}_{2}\right)$ influenced Madurese traders' behavior in paying commercial zakat 
simultaneously. For the sixth, partial test of Likelihood Ratio Sig. Chi-Square X1 $=0.000$ and Sig. Chi-Square X2 $=0.000$ or ChiSquare test $\mathrm{X} 1=15.743$ and $\mathrm{X} 2=20.185$ with degrees of freedom $2=5.99147$. Each variable such as income variable $\left(\mathrm{X}_{1}\right)$ and economic motivation $\left(\mathrm{X}_{2}\right)$ with Chi-Square test $>$ Chi-Square table and significance value $<\alpha$ value $(0.05)$ meant income variable $\left(\mathrm{X}_{1}\right)$ and economic motivation $\left(\mathrm{X}_{2}\right)$ influenced Madurese traders' behavior in paying zakat, partially.

Lastly, parameter estimation test with reference category: never pay zakat commercial. The result of the test indicated category of sometime pay zakat commercial partially,Sig. Wald income $\left(\mathrm{X}_{1}\right)$ had no any influence toward the behavior of sometime paying zakat commercial $(0.101>0.05)$ with Exp (B) value 3.738. In other words, the higher income of the people, the probability to sometime pay zakat commercial multiplied 3.738 than people who never pay zakat commercial by assuming on constant economic motivation variable.

Sig. Wald economic motivation $\left(\mathrm{X}_{2}\right)$ did not influence the behavior of sometime pay zakat commercial $(0.410>0.05)$ with $\operatorname{Exp}(\mathrm{B})$ value of economic motivation 1.082. It meant the higher economic motivation, the probability to behave sometime pay zakat commercial was 1.082 times more that people who never pay zakat commercial with assumption of constant income variable.

Meanwhile, in the category of always pay zakat commercial Sig. Wald income (X1) influenced on the always pay zakat commercial behavior $(0.001<0.05)$ with Exp (B) value of income 16.219 which meant the higher income capability, the probability to always pay zakat commercial was 16.219 times higher than people who never pay zakat commercial on the assumption of constant economic motivation variable.

Sig. Wald of economic motivation (X2) influenced on always pay zakat commercial $(0.000<0.05)$ with Exp (B) value of economic motivation 1.482 which meant the higher economic motivation, the tendency to always pay zakat commercial was 1.482 times higher that they who never pay zakat commercial by assuming on constant income variable.

Income (X1) had positive and significant influence toward Madurese traders' behavior since the higher income would impact on the greater capital tumover for trading. Automatically, their profit would increase and 
their consuming also lifted up. It upsurgethe amount of zakat commercial paid and made them continually paid zakat commercial.

The result of this study goes along with theoretical factors about consumers' buying decision by Setiadi (2010:13) that is economic-state consists of total consumptions' amount (level, stability and pattern), savings, wealth (goods can be cashed), debt capability, and behavior on make others save their money.

In addition, the result of this study also match with discussion by Siswantoro \& Nurhayati (2012) that is the higher income impacts positively on the awareness in paying zakat with the assumption they are consciousto their religion and automatically comply to do their responsibility as mizakki. Besides, their income is considered good enough to pay zakat. If it is compared to this current study, the similarity is on the positive and significant impact on the awareness in paying zakat because of their heart and their orientation on social purpose and religion as well.

Afterwards, Merlinda (2015) found that income level had positive influence toward Moslems' decision in paying zakat as long as it already reach the minimum limit of nisab.
Here, the high income impacted on capital turnover's flow, profit upsurge, rise of consumption as well as the total amount of paid zakat became greater. The similarity with this current study is that there is positive and significant impact on the probability of income and total amount of paid zakat.

The next study by Sobana (2016) found that obedience in paying zakat maal was affected by income capability. The likeness with this current study is the total incomehas positive and significant effect on how much and also how routine people pay their zakat commercial.

Another study conducted by Perbawa and Abdullah (2016) got that income affected positively on the people awareness in paying zakat at BAZNAS. It assumed the high income went along with nisab calculation. Compare to this study, there is positive and significant influence between income capability and the total amount of paid zakat commercial.

Sedjati, et al. (2018) acquired income influenced on the willingness in paying zakat commercial. It was assumed that the high income would affect the willingness in paying zakat because offive pillars of Islam and their responsibility as a Moslem. The similarity 
with this study is that there is positive and significant influence caused by income and it is affecting the amount of zakat.

Economic motivation (X2) influenced positively and significantly toward how people pay their zakat commercial. The higher economic motivation meant the more frequent they paid zakat commercial. It was assumed muzakki believed their economic motivation lead them to distribute the income equally, assisted venture capital productive, helped people in needs to pay their debt off and hope Allah multiplied the wealth so muzakki would pay zakat continually.

Bakar \& Rashid (2010) also contributed to the findings of this study. They found academics from three faculties in International Islamic University of Malaysia (IIUM) who paid zakat were influenced by economic factor: paying zakat could elevate people's economic conditions. It was assumed those academics who paid zakat were oriented in prosperity and social justice so the social gaps could be decreased. The likeness with this current study is the positive and significant influence because the intention of zakat payment is oriented to social purpose, help people in needs to fulfill their necessities.
The ultimate study by Siswantoro \& Nurhayati figured out that motivation had positive and significant impact toward zakat as tax deduction. It was assumed muzakki had awareness in social purpose. The similarity with this present study is there the positive and significant effects caused by they want to alleviate people in needs' burden to fulfill the necessities.

\section{CONCLUSIONS}

All in all, income has positive and significant influence toward muzakki's behavior in paying zakat commercial. It happens since muzakki have already reach their nisab (calculation limit). Also economic motivation, it influences positively and significantly on muzakki's behavior in paying zakat commercial because their social purpose such as enhancing prosperity and helping people in needs to live worthy.

Both government and zakat institutions should socialize more frequently to the society, especially traders, about concept in zakat commercial. This socialization can be in the form of Islamic lecture by ustadz in the mosque. The expected possibility is that people will aware of paying zakat or even reach the level of submissive. YKPN. 


\section{REFERENCES}

Bakar, Nur Barizah Abu \& Rashid, Hafiz Majdi Abdul. 2010. Motivations of Paying Zakat on Income: Evidence from Malaysia. International Journal of Economics and Finance, 2(3), 7684.

BPS. 2015. Malang Dalam Angka 2014. (Online), (http://malangkota.go.id). Accessed onJune $2^{\text {nd }}, 2016$.

BPS. 2015. Malang Dalam Angka 2015. (Online), (http://malangkota.go.id). Accessed on June $2^{\text {nd }}, 2016$.

Ghozali, Imam. 2011. Aplikasi Analisis Multivariate Dengan Program IBM SPSS19, $5^{\text {th }}$ Edition. Semarang: Undip.

Kementerian Agama R.I Direktorat Jenderal Bimbingan Masyarakat Islam Direktorat Pemberdayaan Zakat. 2013. Panduan Organisasi Pengelola Zakat. Jakarta Selatan: Direktorat Jenderal Bimbingan Masyarakat Islam Direktorat Pemberdayaan Zakat.

Merlinda, Santi. 2015. Determinan Keputusan Muslim dalam Pembayaran Zakat Perdagangan (Studi Kasus Di Kota Malang Provinsi Jawa Timur). Thesis. Malang: University of Brawijaya.

Perbawa, Arip \& Abdullah, Rose. 2016. Determinant Factors of Awareness for Paying Zakat on Baznas, Indonesia. SSRN.

Sedjati, Dwi Poetra, Basri, Yuzwar Z dan Hasanah, Uswatun. 2018. Analysis of Factors Affecting the Payment of Zakat in Special Capital Region (DKI) of Jakarta. Intemational Journal of Islamic Business \& Management, 2(1), 24-34 ISSN 2576-7674 E-ISSN 2576-7682.

Siswantoro, D \& Nurhayati, S. 2012. Factors Affecting Concern about Zakat as a Tax Deduction in Indonesia. International Journal of Management and Business Research, 2(4), 293312 .

Sobana, Dadang Husen, dkk. 2016. The Variables that Affect Compliance of Muslim Merchants for Zakat Maal in the District of Cianjur. Intemational Journal of Zakat, 1(1), 78-87.

Sugiyono. 2014. Metode Penelitian kuantitatif, Kualitatif, dan $R \& D, 21^{\text {st }}$ Printed. Bandung: ALFABETA.

Widhiarso, Wahyu. 2010. Pengembangan Skala Psikologi: Lima Kategori Respons ataukah Empat Kategori Respons? Pagel-4.

Widarjono, Agus. 2010. Analisis Statistika Multivariat Terapan, $1^{\text {st }}$ Edition, $1^{\text {st }}$ Printed. Yoyakarta: UPP STIM YKP. 